\title{
Developing a team performance framework utilising Neethling's thinking style preference instrument
}

\begin{tabular}{|c|c|}
\hline \multicolumn{2}{|c|}{$\begin{array}{l}\text { Authors: } \\
\text { Yvonne T. Joubert }^{1} \text { (D) } \\
\text { Christine Swart }^{1} \text { (D) }\end{array}$} \\
\hline \multicolumn{2}{|c|}{$\begin{array}{l}\text { Affiliations: } \\
{ }^{1} \text { Department of Human } \\
\text { Resource Management, } \\
\text { School of Management } \\
\text { Sciences, College of } \\
\text { Economic and Management } \\
\text { Sciences, University of South } \\
\text { Africa, Pretoria, South Africa }\end{array}$} \\
\hline \multicolumn{2}{|c|}{$\begin{array}{l}\text { Corresponding author: } \\
\text { Yvonne Joubert, } \\
\text { joubeyt@unisa.ac.za }\end{array}$} \\
\hline \multicolumn{2}{|c|}{$\begin{array}{l}\text { Dates: } \\
\text { Received: } 03 \text { Apr. } 2019 \\
\text { Accepted: } 24 \text { June } 2019 \\
\text { Published: } 26 \text { Nov. } 2019\end{array}$} \\
\hline \multicolumn{2}{|c|}{$\begin{array}{l}\text { How to cite this article: } \\
\text { Joubert, Y.T., \& Swart, C. } \\
\text { (2019). Developing a team } \\
\text { performance framework } \\
\text { utilising Neethling's thinking } \\
\text { style preference instrument. } \\
\text { SA Journal of Human } \\
\text { Resource Management/SA } \\
\text { Tydskrif vir } \\
\text { Menslikehulpbronbestuur, } \\
\text { 17(0), a1203. https://doi. } \\
\text { org/10.4102/sajhrm. } \\
\text { v17i0.1203 }\end{array}$} \\
\hline \multicolumn{2}{|c|}{$\begin{array}{l}\text { Copyright: } \\
\text { (C) 2019. The Authors } \\
\text { Licensee: AOSIS. This } \\
\text { is licensed under the } \\
\text { Creative Commons } \\
\text { Attribution License. }\end{array}$} \\
\hline \multicolumn{2}{|l|}{ Read online: } \\
\hline 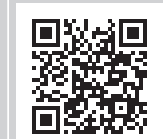 & $\begin{array}{l}\text { Scan this QR } \\
\text { code with your } \\
\text { smart phone or } \\
\text { mobile device } \\
\text { to read online. }\end{array}$ \\
\hline
\end{tabular}

Orientation: This article focuses on the employees and managers' experience of the effects of Neethling's thinking style preference instrument on team performance.

Research purpose: The purpose of this study was to compile a framework to apply Neethling's thinking style preferences to team performance.

Motivation for the study: Organisations today are aware that they need to increase quality, decrease costs, advance customer service, increase their adaptability to an increasingly competitive environment and decrease the time spent on creating new products. To realise these goals, organisations must convert their work teams into more cohesive and dedicated teams. No or limited research has been conducted on how the application of Neethling's thinking style preferences may influence team performance.

Research approach/design and method: A qualitative exploratory study was conducted with 19 participants working in the Financial and Insurance Department of a sales-driven organisation in Gauteng, South Africa. The data were collected by means of focus group and individual interviews.

Main findings: The positive effects of the Neethling's thinking style preferences on the team were that the participants understood people better, their conflict management skills increased, their self-awareness improved, the communication in the team increased and they experienced an increase in team cohesion. The negative experiences were task avoidance, labelling and wrong assessments of people, but the positive experiences exceeded the negative experiences. Due to the positive experiences, the organisation also benefitted in terms of improved customer service and increased productivity, which could lead to organisational success and a competitive advantage.

Practical/managerial implications: When used in teamwork, the Neethling's thinking style preference instrument shows positive outcomes regarding team performance.

Contribution/value-add: The findings of this study contribute new knowledge regarding the application of Neethling's thinking style preferences in team performance.

Keywords: communication; conflict management; customer service; Neethling's thinking style preferences; productivity; self-awareness; team cohesion; team performance.

\section{Introduction}

Organisations today are aware that they need to increase quality, decrease costs, advance customer service, increase their adaptability to an increasingly competitive environment and decrease the time spent on creating new products (Levi, 2014). To realise these goals, organisations must convert their work teams into more cohesive and dedicated teams (Johnson \& Johnson, 2006). Research, as early as the 1950s, has been focusing on effective, competitive organisations and how to build a strong and effective workforce (Grobler, Bothma, Brewster, Carey, Holland, \& Wärnich, 2012). Factors such as employee motivation (Fullen, 2008), the empowerment of employees to do their own decision-making and the decentralisation of decision-making (Grobler et al., 2012) have also received attention.

Numerous benefits are derived when highly effective teams are established (Nedelko, 2008). The benefits include the fostering of creativity and innovation, increased problem-solving, improved quality of decision-making processes, better decisions, enhanced commitment to tasks, and

Note: This article is based on the dissertation by Christine Swart, Neethling's thinking style preferences instrument to enhance team performance in an organisation in South Africa, available at http://uir.unisa.ac.za/bitstream/handle/10500/23527/dissertation_swart_c. pdf?isAll=\&sequence=1. 
improved morale and motivation among employees. Rudansky-Kloppers and Strydom (2015) added other benefits to this list, such as improved sharing of information and improved cooperation. Teams are therefore better than the individuals they comprise.

However, to build a dynamic and highly motivated team is a complex and challenging task (Rudansky-Kloppers \& Strydom, 2015). Many new techniques to improve teams have appeared over the past decades, but several challenges still remain, such as costs and commitment (Katzenberg \& Smith, 2015). The aim of this study was to compile a framework to apply Neethling's thinking style preferences to teams, with the idea that the instrument would enhance performance. Because there is no or limited literature available on Neethling's thinking style preferences in respect of team performance, this research will enlarge the knowledge base and should add significant academic value to the field of Human Resource Management and, more specifically, team performance.

\section{Literature review}

In this section, the importance of teams and Neethling's thinking style preferences will be discussed.

\section{The importance of teams}

It is essential to understand the meaning of team effectiveness to utilise teams to improve the success of an organisation and for the organisation to benefit from the use of teamwork and teams (Pina, Martinez, \& Martinez, 2008; Ross, Jones, \& Adams, 2008). It is therefore important to be aware of the three criteria for effective teams: member satisfaction, team viability and task performance (Fiske, Gilbert, \& Lindzey, 2010). Member satisfaction means that effective teams are content with their team accomplishments, interpersonal relationships and team tasks. Team viability implies that teams are cohesive and work well together as a team. Task performance means that time efficiency, quality and quantity are achieved by effective teams (Schermerhorn, Osborn, Uhl-Bien, \& Hunt, 2012).

However, it is not an easy task to put effective and successful teams together. Some of the challenges that teams face are that the teams not always perform well and team members are not always satisfied (Fiske et al., 2010); personality conflicts and different work styles antagonise some members and disrupt accomplishments and relationships (Schermerhorn et al., 2012); lack of coordination and cooperation, support systems and listening and communication, and poor interpersonal relationships hamper teams (Rudansky-Kloppers \& Strydom, 2015); members of the team sometimes do not understand themselves and a lack of understanding of team work processes may exist (Cameron \& Green, 2012); and internal competition, inadequate discussion of differences and a lack of focus on mutual goals (Forsyth, 2010) might hinder the performance of a team. Other underlying aspects in the design of teams, such as the nature of the team task, membership composition, team processes, team size, team performance and team setting and resources, also play a significant role in team effectiveness (Weiner, 2012). Shore, Coyle-Shapiro, and Tetrick (2012) express their concern that teams will fail if organisations commit to the virtues of teamwork, but do nothing to ensure teamwork as part of the employee work paradigm.

\section{Overcoming barriers to team effectiveness: Developing successful teams}

To overcome the barriers to effective teams, a number of vital interventions are required, which include understanding team members, conflict management, enhancing communication and team cohesion.

\section{Members do not understand one another}

If a work team do not understand one another, the team will probably be unsuccessful. Team members need to understand and realise that other team members are different and unique. This understanding can be used to foster a work environment that increases the vision for personal growth and productivity (Cameron \& Green, 2012; Joubert, 2012; Stickley \& Basset, 2008). Puth (2008) agrees with this view by arguing that leaders and members of a team have to gain an understanding of the different roles among them to appreciate each other's competencies and talents, which will improve the team's performance (Sharp, Hides, Bamber, \& Castka, 2000).

\section{Conflict}

It is imperative for an effective team to be able to manage conflict efficiently. Although limited conflict may stimulate team activity, too much energy, that could have been used to attain the goals of the team, is wasted when members focus on interpersonal conflict. Excessive conflict leads to poor team member cooperation and disruptive behaviours (Jehn \& Mannix, 2001; Rudansky-Kloppers \& Strydom, 2015; Stone \& Redmer, 2006).

\section{Open communication}

A team can only function effectively when there is effective two-way communication among the members (PatrashkovaVolzdoska, McComb, Green, \& Compton, 2003; Pinto \& Pinto, 1991). Members must recognise that their goals should be aligned with the other units in the organisation and that they exist in an organisational context. The success of a team depends on effective communication between team members and sharing knowledge (Bergiel, Bergiel, \& Balsmeier, 2008; Joubert, 2012).

\section{Cooperation and team cohesion}

A basic prerequisite for team success is a cohesive team. Team cohesiveness and cooperation are vibrant processes that reflect the propensity of a group of individuals to stay together and unite in aspiring one another to obtain specific objectives and goals (DuBrin \& Dalglish, 2003; Tekleab, Quigley, \& Tesluk, 2009). Alvarez, Butterfield, and Ridgeway (2013) agree with this statement by saying that a lack of team 
cohesion will affect the team's performance because of unnecessary stress and tension among the members. Team efficacy occurs when members of the team are confident and if they believe that they can thrive (Jung \& Sosik, 2003; Robbins \& Judge, 2009). Gibson, Ivancevich, Donnelly, and Konopaske (2009) elaborate on this by indicating that team members need to work together as it will improve the productivity in the organisation and the members' morale.

\section{Customer service and product delivery}

If a team is not able to provide satisfactory service to customers and the organisation is not able to be productive, it will result in ineffective teams (Joubert, 2012). Hackman (2002) contends with this statement by saying that a team is most likely to be effective when customer expectations in product and service delivery are exceeded, capabilities in a team are developed over a period of time and that the team members' needs are satisfied (Swart, 2017).

\section{Neethling's thinking style preferences}

Neethling (2005) divided the four brain quadrants into two dimensions per quadrant, which resulted in an eightdimensional brain profile. The four quadrants are the L1 quadrant (the analyst and realist); the L2 quadrant (the organiser and stalwart); the R1 quadrant (the imaginer and strategist) and the R2 quadrant (the empathiser and socialiser). Figure 1 depicts the four different brain quadrants.

An individual's actions are determined by his or her dominant brain quadrant. That is why thinking, decisionmaking, communication and learning differ from person to person. The term 'whole brain thinking' means being able to fully control your own preferences, being able to move to other quadrants when necessary and being able to take

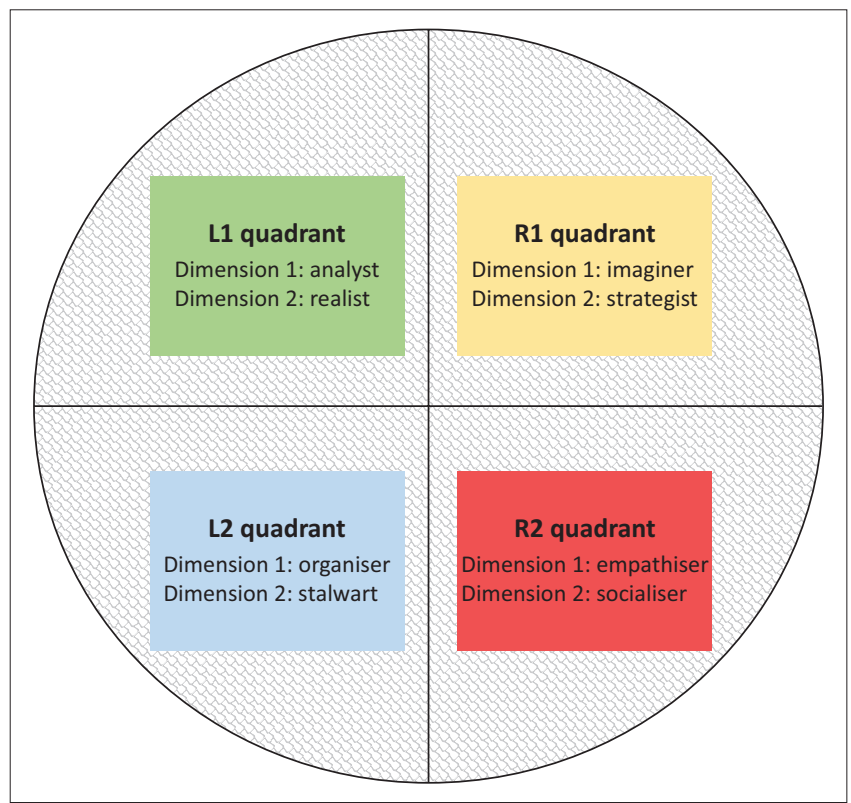

Source: Adapted from Swart, C. (2017). Neethling's thinking style preference instrument to enhance team performance in an organisation in South Africa. Unpublished MCom dissertation. Pretoria: University of South Africa

FIGURE 1: The four brain quadrants. advantage of and adapt to the preferences of the people around you to improve optimal performance (Herrmann \& Herrmann-Nehdi, 2015).

The advantages of this concept of whole brain thinking are that individuals can come to understand their thinking preferences, which assist them in adapting their thinking and optimising their abilities, and improve communication and decision-making styles, regardless of the situation. It also clarifies to these individuals why it is easier for them to communicate with certain people, what they should focus on, what they learn best and what motivates them (Neethling, 2005; Swart, 2017). These advantages could influence the way members in a team operate in a work environment.

As indicated in our previous section, teams play a crucial role and any attempt to increase effective teamwork through new methods, such as the Neethling's thinking style preferences, could add value to team performance and ultimately organisational success. No or limited research has been conducted on how the application of Neethling's thinking style preferences may influence team performance.

\section{The input-process-output model}

The researchers decided to include the input-process-output model in this article because the inputs of a team are factors that may limit or add to team processes (Mathieu, Maynard, Rapp, \& Gilson, 2008). Figure 2 is a graphical illustration of the input-process-output model.

Inputs include factors on the organisational level (such as rewards), group level (such as group size and group task) or individual level (such as expertise and personality characteristics). They influence team processes (for instance, improve conflict or communication skills) and represent the members of the team's interactions in reaching goals (Marks, Mathieu, \& Zaccaro, 2001). The team processes, in turn, influence the team outcomes (such as task performance and member attitudes). Although a selection of team inputs and outcomes are examined in the literature on traditional team effectiveness, new research on team processes is still required (Marks et al., 2001; Mathieu et al., 2008). There is

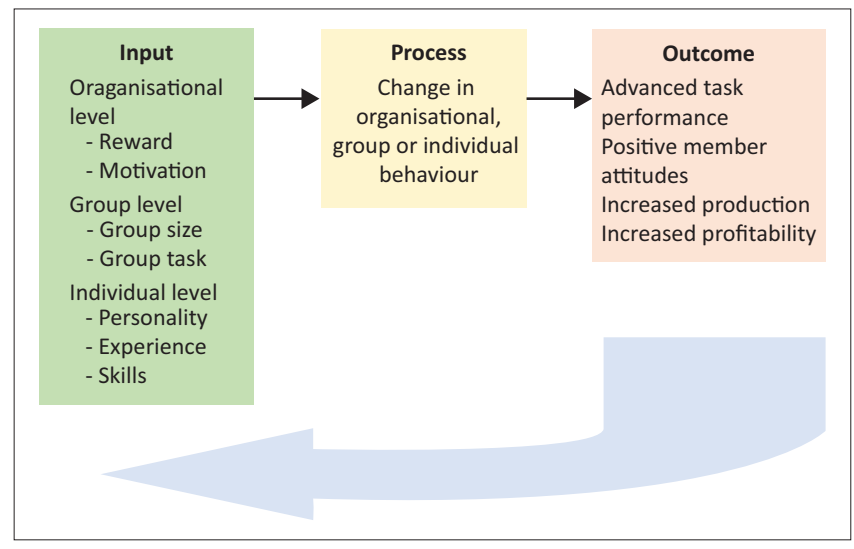

Source: Adapted from McGrath, J.E. (1964). Social psychology: A brief introduction. New York: Holt

FIGURE 2: The input-process-output framework. 
therefore a need for this study, and it should make a significant contribution to the field of Human Resource Management and, more specifically, team performance.

\section{Research design}

According to Welman, Kruger, and Mitchel (2005), a research design is a plan that the researcher uses to collect data from the participants. The research question gives focus to the study and provides direction on how to conduct the research (Maxwell, 2013).

\section{Research approach}

In this study, a qualitative approach was most appropriate because the essence of the study was to explore the perceptions of participants. In-depth focus group interviews with employees, as well as individual interviews with managers, were conducted. A total of 19 participants participated in this study. The interviews were semistructured and open-ended and participants were asked to explain their perceptions of team performance as it relates to Neethling's thinking style preferences. The primary researcher focused on the perceptions and views of managers and employees and aimed to interpret them to gain a better understanding of the subject at hand. This exploration was necessary, as no other research has previously been conducted on Neethling's thinking style preferences in respect of team performance, which would have enabled the researcher to follow a quantitative research approach. The data obtained from the interviews were deemed to be reliable as the primary researcher's own perceptions, ideas and views were excluded from the study (Babbie, 2008). The four criteria of trustworthiness (credibility, transferability, dependability and confirmability) were applied (Guba \& Lincoln, 1994).

To achieve the aim of this research study, two theories were used. Firstly, a grounded, interpretivist approach was used because of its organised stance towards listening and gaining an understanding of the employees and managers' views and perceptions. The goal of grounded theory is to collect data and to analyse it, whereupon assumptions can be made, which are 'grounded' on the data (Brink, Van Der Walt, \& Van Rensburg, 2006). Data were collected from the employees and managers who were working in a finance and insurance department in a sales-driven organisation and who had undergone three or more training sessions in Neethling's thinking style preference. Secondly, an interpretivist approach was used because the primary researcher wanted to explain the multiple perceptions of the participants (Andrade, 2009). An inductive strategy was used to identify patterns of responses and to interpret them, as no or limited literature exists that would enable the authors to provide a framework for understanding the topic of this study (Merriam, 1998).

\section{Research strategy}

A finance and insurance department in a sales-driven organisation in Gauteng, South Africa, was selected.
Two focus group interviews with employees and six individual interviews with managers were conducted. Nineteen participants took part voluntarily and were encouraged to talk about their experience.

Non-probability, purposive and snowballing sampling was used for this study, as the research problem was to be addressed with a specific plan and the primary researcher had a specific purpose in mind (Kothari, 2004). The sample in this study was selected on the basis of specific criteria and was small (Ritchie \& Lewis, 2003). The criteria to select participants for this study were that they all had to have undergone three or more training sessions in Neethling's thinking style preferences, were employed in the particular sales-driven company in Gauteng, South Africa, were working in the financial and insurance department and were willing to be interviewed in either a focus group or individual interview.

\section{Research method}

The following aspects of the research method followed in this study are discussed below: population and sampling, data collection methods, recording of data, data analyses and strategies employed to ensure quality data and reporting.

\section{Research setting}

The research setting consisted of all employees employed at the financial and insurance department of a sales-driven organisation in South Africa.

\section{Entrée and establishing researcher roles}

In qualitative research studies, the researcher is the primary instrument for gathering and analysing data. Subjectivity is part of an interpretive research process that makes it possible to understand social and personal realities with empathy. Subjectivity is beneficial to the process, as the personal experience of a researcher is added to the participants' experience (Peshkin, 1988).

The training manager, where this research was conducted, acted as the gatekeeper to participants and set up an interview schedule for the participants who partook in the in-depth interviews. The research was explained and written permission was obtained to conduct interviews with voluntary participants.

All participants signed a consent form, and the context and the purpose of the study were explained to them. Participation was voluntary, and confidentiality of participation and information was ensured. A convenient place and time was scheduled with the participants.

\section{Population and sampling}

The population for this study consisted of all employees employed at the financial and insurance department of a sales-driven organisation in South Africa who had undergone 
TABLE 1: Biographical characteristics of total participants.

\begin{tabular}{|c|c|c|c|c|c|c|c|}
\hline Participant & Race & Age & Gender & Nature of job & Time lapse since training & Neethling's training sessions & Brain profiles \\
\hline \multicolumn{8}{|c|}{ Biographical characteristics of individual interviewees } \\
\hline 1 & White people & $46-55$ & Male & Management & $1-6$ months & 5 sessions & L2 \& R1 \\
\hline 2 & Mixed race & $46-55$ & Male & Management & $1-6$ months & 3 sessions & L1 \& L2 \\
\hline 3 & White people & $46-55$ & Male & Management & $1-6$ months & 4 sessions & $\mathrm{R} 1$ \& R2 \\
\hline 4 & White people & $46-55$ & Male & Management & $1-6$ months & 4 sessions & L1 \& L2 \\
\hline 5 & White people & $31-45$ & Female & Management & $1-6$ months & 4 sessions & L1 \& L2 \\
\hline 6 & White people & $46-55$ & Male & Management & $1-6$ months & 5 sessions & L1 \& L2 \\
\hline \multicolumn{8}{|c|}{ Biographical characteristics of focus group 1} \\
\hline 7 & White people & $31-45$ & Female & Professional & $1-6$ months & 3 sessions & L1 \& L2 \\
\hline 8 & White people & $46-55$ & Male & Professional & $1-6$ months & 4 sessions & L1 \& R2 \\
\hline 9 & White people & $31-45$ & Female & Professional & $1-6$ months & 4 sessions & L1 \& L2 \\
\hline 10 & Black people & $31-45$ & Female & Professional & $1-6$ months & 4 sessions & L1 \& L2 \\
\hline 11 & Black people & $31-45$ & Female & Professional & $1-6$ months & 3 sessions & L1 \& R1 \\
\hline 12 & Black people & $31-45$ & Female & Professional & 6 months -1 year & 3 sessions & L1 \& R1 \\
\hline \multicolumn{8}{|c|}{ Biographical characteristics of focus group 2} \\
\hline 14 & Black people & $31-45$ & Female & Professional & $1-6$ months & 3 sessions & L1 \& L2 \\
\hline 15 & White people & Older than 55 & Male & Professional & Longer than 1 year & 3 sessions & $\mathrm{R} 1$ \& R2 \\
\hline 16 & White people & $31-45$ & Female & Professional & $1-6$ months & 4 sessions & L2 \& R2 \\
\hline 17 & White people & $31-45$ & Female & Professional & $1-6$ months & 4 sessions & L1 \& R1 \\
\hline 18 & White people & $31-45$ & Female & Professional & $1-6$ months & 4 sessions & L1 \& L2 \\
\hline 19 & White people & $31-45$ & Female & Professional & $1-6$ months & 3 sessions & L2 \& R1 \\
\hline
\end{tabular}

Source: Swart, C. (2017). Neethling's thinking style preference instrument to enhance team performance in an organisation in South Africa. Unpublished MCom dissertation. Pretoria: University of South Africa

three or more sessions in Neethling's thinking style preferences training.

The biographical characteristics of all of the participants who were part of this study are presented in Table 1.

\section{Data collection methods and recording of data}

A prearranged place and time for the interviews were organised with the participants. The focus group interviews were conducted at the training centre where the participants had their training sessions and the six individual interviews were conducted in the boardroom of the organisation. The interviews took approximately $1 \mathrm{~h}$ each. Guided interviews were used in this study. The semi-structured interviews allowed the primary researcher to achieve the research aim and participants were afforded the opportunity to express themselves freely (Hein, 1980). A reliable audio recorder was used for the interviews (Kvale, 1996). The researcher compiled observation notes and field notes that contained facts about the interviews, the setting and the researcher's personal impressions and feelings. Two questions were asked which enabled the researcher to collect the data for the study. The two questions asked during the focus group and individual interviews were the following:

1. In your experience/to your knowledge, what is the effect of Neethling's thinking style preferences on your team's performance?

2. In your opinion, would you say that the Neethling's thinking style preference instrument is a viable tool for enhancing team performance?

This qualitative research project relied on the primary researcher for data gathering and analysis. Recurring ideas and themes and important concepts were gleaned from the transcripts. The data-recording process proposed by Tesch (1990) was used. Consideration was given to themes and ideas that could be categorised into a number of broader groups. The completed transcripts were reviewed to identify any concepts that were not initially noted. Variations and similarities in data from different interviews were noted. The data were stored and password protected on the primary researcher's computer. The participants remained anonymous.

The possibility of bias was curtailed through peer review. The researcher's study supervisor reviewed the interviews, transcriptions, analysis and coding. The findings cannot be generalised because this study was conducted in one company. When considering the transferability of the findings, the context in which the study was conducted should be taken into account.

\section{Data analyses}

During the data analysis phase, the relevant data were assessed and grouped into broader categories (LobiondoWood \& Haber, 2017). The primary researcher and her supervisor analysed the data themselves, and it was unnecessary to utilise a more formal method such as the Atlas TI or GABEK data analysis programmes. Tesch's (1990) data analysis method was used for the study. Apart from the transcriptions of the recorded interviews, notes made on witnessed expressions during the interviews were used in the data analysis. The most interesting individual interview was selected as a starting point to identify the main codes. Thereafter all the other interviews were coded and a list of key words was compiled. Key words with similar meanings were grouped together into topics. The topics were abbreviated as codes and written next to the appropriate parts of the text. The most descriptive wording was found for 
each code and from that themes were created by clustering meaning-related codes together. A final decision was then made on the labelling for each theme. The grouping of the material within the themes was then done based on reflection on how the themes related to one another and to the research phenomenon. The last step was to report the findings.

\section{Theory building}

The aim of this research was to compile a framework to apply Neethling's thinking style preferences to teams, with the idea that the instrument would enhance performance. The researchers used the Theory Building Model of Carlile and Christensen (2004) to develop a team performance model. During the descriptive phase, (inductive) data were collected through individual and focus group interviews (Carlile \& Christensen, 2004). Thereafter the data were described and constructs were developed that helped the researchers to understand what effect the Neethling's thinking style preference instrument had on team performance (Carlile \& Christensen, 2004). The next step was to group the constructs into categories (Carlile \& Christensen, 2004). During categorisation, differences and similarities between the categories were explored, as well as the relationships between them (Carlile \& Christensen, 2004). The last step in the descriptive phase was to explore the relationships between the categories.

During the next stage, the normative or deductive stage, the theory was tested on new data to confirm or highlight anomalies that resulted in a review of the theory, its categories, the relationships between them and their relationship to the outcome (Carlile \& Christensen, 2004). In particular, it was important to explore what caused these different circumstances (anomalies) and why they occurred. The causes of the anomalies were further explored and were then used to modify the model and theory to clearly explain what would and would not lead to the desired outcome (Carlile \& Christensen, 2004).

\section{Strategies employed to ensure the quality of the data}

The researchers re-assessed the data continuously until there was a common understanding, to ensure the quality of the data. Themes and patterns emerged during the data analyses. The researchers' authority enhanced the quality of the research. The researchers established their authority by means of the primary researcher's involvement in Neethling's thinking style preference instrument training, and their extensive knowledge of the subject (Krefting, 1991).

\section{Ethical considerations}

Written permission was obtained from the training manager to conduct this research at their company. Following the initial contact with the participants, the primary researcher set up a discussion with them, during which the aim and nature of the study and the relevant ethical parameters such as confidentiality, freedom to withdraw and anonymity were once again explained. The participants signed informed consent forms before the individual and focus group interviews were conducted. Before each interview, the primary researcher explained the aim of the research. The study also received ethical clearance from the Research Institution at the University of South Africa and was conducted under the ambit of the ethics policy of UNISA (UNISA, 2013).

\section{Findings}

Each participant's experience was relevant to his or her own views, and experience relating to the effect the Neethling's thinking style preference instrument has on team performance. Two themes arose from the answers obtained from the first interview question (In your experience/to your knowledge, what is the effect of Neethling's thinking style preferences on your team's performance?):

Theme 1: Neethling's thinking style preferences improve performance of the team

Theme 2: Neethling's thinking style preferences improve organisational outcome goals

\section{Theme 1: Neethling's thinking style preferences improve the performance of the team}

Ten participants (participants 1, 2, 3, 6, 9, 12, 13, 15, 16 and 19) were of the view that the application of the Neethling's thinking style preferences increased their team's understanding of people. Participant 6 (White, male, 5 Neethling training sessions) indicated that '(w)e understand people now. We understand what makes the other people tick and how to work with them'. Participant 12 (Black, female, 3 Neethling training sessions) said, 'It makes you understand other people a lot better as well because then you know there's leftbrain people, right-brain people and you know that we're not all the same' and Participant 15 (White, male, 3 Neethling training sessions) was of the view that '(y)ou recognise characteristics, it's easier to get along with someone because you know where they're coming from. Knowledge is power'.

Cameron and Green (2012) maintain that team members not understanding one another are unable to manage diversity, have little knowledge of team behaviour and do not understand the processes in the team that have a negative impact on team performance. Puth (2008) argues that it is important for the leader and members of a team to gain an understanding of the members' different roles within the team to appreciate each one's talents and competences, which will improve the team's performance.

Participants 1, 4 and 9 also concurred that their conflict management abilities increased with their knowledge of the Neethling's thinking style preferences. Participant 1 (White, male, 5 Neethling training sessions) said, 'By understanding what someone's like, you can resolve conflict a lot easier, so it's all about communication and emotional intelligence'. Participant 9 (White, female, 4 Neethling training sessions) 
indicated '(1)ess conflict - we're dealing with it better because we understand each other'. Rudansky-Kloppers and Strydom (2015) posit that if conflict is managed well, it will result in positive outcomes such as improved conflict resolution, improved relationships in a team and improved problemsolving. Jehn and Mannix (2001) state that effective conflict management impacts positively on team performance and cohesiveness.

Eight participants (participants 3, 5, 9, 10, 13, 14, 15 and 19) were of the view that their self-awareness improved after they received training on Neethling's thinking style preference instrument. Participant 10 (Black, female, 4 Neethling training sessions) remarked that because:

'[W]e have been to this course and other people haven't been, you have to take a step back and look at the situation before you deal with them. Otherwise, if you're the one who's not going to lead by example, then all your hard work is going to waste. You have to be aware of what you're feeling and what other people feel and have self-awareness before you can respond and act.'

Participant 13 (Black, female, 4 Neethling training sessions) concurred by saying 'I think, knowing myself- first of all on which things I prefer with regard to my way of thinking' and participant 15 (White, male, 3 Neethling training sessions) said, 'It makes you confident with yourself as well. You know your own strengths and you can focus on improving your strengths as it is your natural default'.

The participants (participants 1, 3, 4, 5, 6 and 8) said that their communication increased after they started applying their knowledge of Neethling's thinking style preferences. Participant 4 (White, male, 4 Neethling training sessions) stated, 'The way they communicate - yes, team members communicate better' and participant 6 (White, male, 5 Neethling training sessions) said, 'Our communication is greatly enhanced'. Bergiel et al. (2008) found that one of the requirements for effective team performance is effective twoway communication. They were of the view that success in a team depends on effective communication between team members and on members sharing their knowledge with other team members.

The participants (participants 3, 4, 7, 9, 15, 16 and 19) concurred that their team cohesion increased after applying their knowledge of Neethling's thinking styles in the group. Participant 4 (White, male, 4 Neethling training sessions) said, 'Understanding how the team thinks, understanding how they do things differently, and working towards the same goal increased the relationship among team members'. Participant 9 (White, female, 4 Neethling training sessions) was of the view that there was better cooperation between the members of the team and participant 16 (White, female, 4 Neethling training sessions) indicated that '(b)eing able to understand each other's thinking style preferences has improved the team spirit within the team'. DuBrin and Dalglish (2003) posit that a major strategy in developing an effective team is to promote cooperation between the team members and to make them understand that working together effectively is an expected standard of conduct. Alvarez et al. (2013) maintain that a lack of team cohesion will affect team performance because of the unnecessary tension and stress between team members. Cohesiveness is therefore a determining and crucial factor for team effectiveness.

\section{Theme 2: Neethling's thinking style preferences improve organisational outcome goals}

Seven participants (participants 1, 5, 8, 15, 16, 17 and 19) said that the customer service in the organisation improved after applying their knowledge of Neethling's thinking style preferences. Participant 8 (White, male, 4 Neethling training sessions) said, 'Because we are able to read and understand customer's thinking style preferences better, we've improved in the closure of deals' and Participant 15 (White, male 3 Neethling training sessions) said:

'If you know the customers are left-brain or right-brain then the rest comes into play, how to interact, and you adjust your behaviour to suit them as a customer. If you look at it from that point of view, you understand them and their needs better.'

Hackman (2002) contends that exceeding customer expectations in service and product delivery is a function of team effectiveness, which comes about from developing team capabilities over a period and satisfying the needs of team members, which then leads to team performance.

The participants (participants 2, 6, 8 and 16) were all of the view that the productivity increased after they applied their knowledge of the Neethling's thinking style preferences in the organisation. Participant 2 (Coloured, male, 3 Neethling training sessions) noticed that '... our belief in the Neethling training has actually helped us to grow the F\&I department in terms of the income we generate for the group and for the organisation' and participant 6 (White, male 5 Neethling training sessions) agreed that there were 'better results as far as the working environment goes'. Participant 8 (White, male, 4 Neethling training sessions) said, 'Because we are able to read and understand customer's thinking style preferences better, we've improved in the closure of deals and we are more profitable in our deals'. Robbins and Judge (2009), as well as Jung and Sosik (2003), are of the view that team efficacy occurs when team members are confident and if they believe that they can thrive. A successful team's views about future accomplishments are more positive and productivity increases, which inspire the team members to work harder. This will lead to improved team performance.

Only three participants perceived possible disadvantages when applying knowledge of Neethling's thinking style preferences in an organisation. Participant 2 (Coloured, male, 3 Neethling training sessions) was of the view that tasks could be avoided:

'There's some of our managers that abuse the fact they're right brain. They will have, for argument's sake, got to do something but they won't do it properly because they are a right brain person.' 


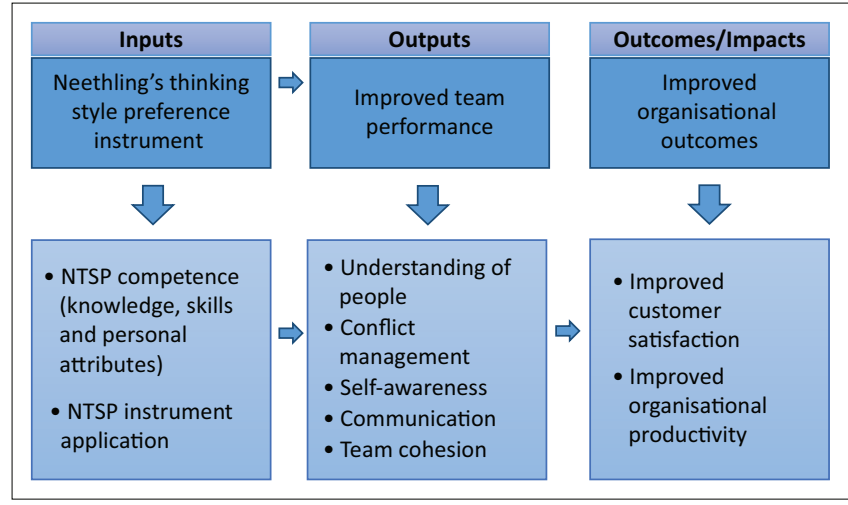

Source: Swart, C. (2017). Neethling's thinking style preference instrument to enhance team performance in an organisation in South Africa. Unpublished MCom dissertation. Pretoria: University of South Africa

FIGURE 3: Conceptual framework of the effect of Neethling's thinking style preference instrument (NTSP) on team performance.

Participant 3 (White, male, 4 Neethling training sessions) said that labelling could be another disadvantage and said that:

'[T] he only disadvantage in my view potentially is that you get labelled. Your friends and colleagues now know that you fit into a specific category and it is now your label, so you are that person and so anything that happens is because you are that person. You are now put into a specific box ...'

Participant 16 (White, female, 4 Neethling training sessions) said that you might sometimes assess someone wrongly:

'Wrongly assessing the client, for instance, you might think that the client is an L2 and you start pointing out every little detail because you know that L2s love detail when in actual fact the client might be an R1 who doesn't like detail at all, so you potentially lose a client.'

The same two themes (Theme 1: Neethling's thinking style preferences improve performance of the team and Theme 2: Neethling's thinking style preferences improve organisational outcome goals) arose from answers obtained from the second interview question (In your opinion, would you say that the Neethling's thinking style preference instrument is a viable tool for enhancing team performance?).

\section{Theme 1: Neethling's thinking style preferences improve performance of the team}

Seven participants (participants 1, 2, 3, 4, 5, 6 and 13) were of the opinion that the Neethling's thinking style preferences improved their understanding of other people. Participant 1 (White, male, 5 Neethling training sessions) said:

'The upswing of understanding how someone works has really been a revelation for us and, as I say, we really believe in this, we've put every single F\&I through the whole process a couple of times and it's been working well. We subscribed to every single one of us, I mean, it's a philosophy, it's part of our DNA if you want to call it, we can speak the same language, people talk about different brain profiles to each other, so we speak the language of the lessons we've learned.'

Participant 6 (White, male, 5 Neethling training sessions) concurred by saying:
'It enables you to work a lot closer with your colleagues because you're able to identify well, which dominance, which quadrant is their dominance and you can talk to them in their language, instead of clashing with them all the time.'

In a study by Sharp et al. (2000) where the Myers-Briggs Type Indicator (MBTI) was used to determine personal differences, it was found that an understanding of personal differences leads to the overall improvement of team performance.

Three participants (participants 1, 5 and 6) were of the view that the Neethling's thinking style preferences increased communication. Participant 5 (White, female, 4 Neethling training sessions) indicated that ' $(\mathrm{t})$ he communication within my team and with the different management teams that we meet with on a quarterly basis have improved a lot' and participant 6 (White, male 5 Neethling training sessions) said, 'Our communication is greatly enhanced.' PatrashkovaVolzdoska et al. (2003) and Pinto and Pinto (1991) found that increased levels of communication between team members are a key to effective team performance.

Both participant 3 (White, male, 4 Neethling training sessions) and participant 6 (White, male, 5 Neethling training sessions) were of the view that the Neethling's thinking style preferences improved team cohesion. Participant 3 (White, male, 4 Neethling training sessions) said, 'People are now getting along with people that they never used to get along with'. Participant 6 (White, male, 5 Neethling training sessions) concurred by saying 'Our personal relationships are greatly enhanced and if you have a better relationship with the people you work with, it will increase team performance.' The degree to which team members are comfortable with one another and experience a feeling of belonging contributes to team effectiveness and team performance (Tekleab et al., 2009).

\section{Theme 2: Neethling's thinking style preferences improve organisational outcome goals}

Participants 3, 4 and 5 said that the Neethling's thinking style preferences improved customer service. Participant 3 (White, male, 4 Neethling training sessions) indicated that:

'[W]hen you meet new people or customers, you are able to fairly and accurately get an idea of who that person is and what they want and what they don't want and thereby you can adjust your approach to them which leads to better customer service.'

Participant 5 (White, female, 4 Neethling training sessions) opined that ' $(\mathrm{t})$ he training enabled us to also deal with customers that phone in complaints better, so the communication to me is key'. In a study by Joubert (2012), it was found that dissatisfied customers and loss of productivity are the end results of a team not being able to work together.

Four participants (participants 2, 7, 10 and 13) felt that Neethling's thinking style preferences improved organisational 
productivity. Participant 2 (Coloured, male, 3 Neethling training sessions) said:

'Our belief in this has actually helped us to grow the department in terms of the income we generate for the organisation. I think it's a viable tool because as some people are strong left-brain and some people are right-brain, we complement each other and because of us being so diverse and understanding, we actually make use of each other's strengths.'

Participant 13 (Black, female, 4 Neethling training sessions) indicated that '(b)ecause people are able to work together, it improves on achieving goals'. Gibson et al. (2009) contend that members in a team need to work together because successful participation in a team improves the morale of the members, as well as processes and productivity in the organisation.

\section{Discussion}

Figure 3 is an integrated framework obtained from the findings in the previous section. It summarises the effect that the Neethling's thinking style preference instrument has on team performance.

The framework is based on the input-process-output system model of McGrath (1964). According to this system, an effective initiative influences employees and the organisation's outcomes. The input in this model consists of employees' competence in applying Neethling's thinking style preference instrument, which includes their knowledge and skills gained from training and their personal attributes.

The results in this study indicate that when team members applied the competencies gained from the their training in Neethling's thinking style preferences, it resulted in improved team performance as an output. Self-awareness, understanding other team members better and better management of conflict were manifested. It also led to improved communication between team members and other stakeholders, as well as cohesion in the team. Team members' productivity and customer service were also enhanced.

When a team's performance improves, it has a positive effect on the organisational goals. These goals included improved customer satisfaction, profitability, organisational image and productivity.

\section{Contribution of the study}

This study involves original research and contributes new knowledge to the field of Human Resource Management and, more specifically, team performance. It also yielded new knowledge with regard to the application of Neethling's thinking style preferences. No previous research was conducted on Neethling's thinking style preferences with regard to team performance.

\section{Limitations}

Certain limitations such as the participant effect and researcher bias, and limitations in terms of data collection and analysis were identified. The primary researcher's longstanding association with Neethling's whole brain practices might have increased bias, but to prevent this, the researcher implemented bracketing, reflexivity and intuiting in all the phases of the study. The primary researcher's supervisor reviewed the transcribed interviews and was also involved in the analysis of the data. Too few mixed race and Indian men and Indian women formed part of this research. Because this study was conducted in one organisation, the findings cannot be generalised. When considering the transferability of the findings, the context in which the study was conducted should be taken into account.

However, based on the conclusions drawn from the findings in this study, recommendations could be made for the implementation of Neethling's thinking style preference instrument in organisations to enhance team performance.

\section{Recommendations}

It is recommended that this research be repeated to include more differentiation of organisations and a larger sample group. It is also recommended that a comparative study be conducted, where international organisations are included.

It is further recommended that employees be trained in Neethling's thinking style preferences to enhance team performance in the organisation, which will ultimately contribute to organisational success.

\section{Conclusion}

The objective of the study was to compile a framework of Neethling's thinking style preference instrument as it applies to team performance.

The positive effects of Neethling's thinking style preferences on the team were that the participants understood people better, their conflict management skills increased, their selfawareness improved, the communication in the team increased and they experienced an increase in team cohesion. There were, however, also negative experiences such as task avoidance, labelling and wrong assessments of people, but the positive experiences exceeded the negative experiences. As a result of the positive experiences of the team, the organisation is likely to benefit from improved customer service and increased productivity, which will lead to organisational success and a competitive advantage.

It is therefore recommended that Neethling's thinking style preference instrument be used as a viable tool to improve team performance, which, in turn, leads to the achievement of overall organisational success. 


\section{Acknowledgements Competing interests}

The authors declare that they have no financial or personal relationships that may have inappropriately influenced them in writing this article.

\section{Author(s) contributions}

All authors contributed equally to this work.

\section{Funding information}

This research received no specific grant from any funding agency in the public, commercial or not-for-profit sectors.

\section{Data availability statement}

Data sharing is not applicable to this article as no new data were created or analysed in this study.

\section{Disclaimer}

We declare that the submitted article is our own work and that all the sources that we have used or quoted have been indicated and acknowledged by means of complete references.

\section{References}

Alvarez, A., Butterfield, L., \& Ridgeway, D. (2013). Building group cohesion in the workplace. Clinical Psychology Associates of North Central Florida. Retrieved from http://cpancf.com/articles_files/buildinggroupcohesionintheworkplace. html.

Andrade, A.D. (2009). Inerpretive research aiming at theory building: Adopting and adapting the case study design. The Qualitative Report, 14(1), 42-60.

Babbie, E. (2008). The basics of social research (4th edn.). London: Thomson Learning.

Bergiel, B.J., Bergiel, E.B., \& Balsmeier, P.W. (2008). Nature of virtual teams: A summary of their advantages and disadvantages. Management Research News, 31(2), 99-110. https://doi.org/10.1108/01409170810846821

Brink, H., Van Der Walt, C., \& Van Rensburg, G. (2006). Fundamentals of research methodology for health care professionals ( 2 nd edn.). Cape Town: Juta.

Cameron, E., \& Green, M. (2012). Making sense of change management: A complete guide to the models, tools, and techniques of organisational change (3rd edn.). London \& Philadelphia, PA: Kogan Page.

Carlile, P.R., \& Christensen, C.M. (2004). The cycles of theory building in management research. (Harvard Business School Working Paper No. 05-057). Boston, MA: Harvard Business School.

DuBrin, A.J., \& Dalglish, C. (2003). Leadership: An Australasian focus. Brisbane: Wiley.

Fiske, T., Gilbert, D.T., \& Lindzey, G. (Eds.). (2010). Handbook of social psychology (5th edn.). Hoboken, NJ: Wiley.

Forsyth, D.R. (2010). Group dynamics (5th edn.). Boston, MA: Wadsworth Cengage Learning.

Fullen, M. (2008). The six secrets of change: What the best leaders do to help their organisations survive and thrive. New York: Wiley.

Gibson, J.L., Ivancevich, J.M., Donnelly, J.H., \& Konopaske, R. (2009). Organisations: Behavior, structure, process (13th edn.). New York: McGraw-Hill.

Grobler, P., Bothma, R., Brewster, C., Carey, L., Holland, P., \& Wärnich. S. (2012) Contemporary issues in human resource management: Gaining a competitive advantage (4th edn.). Cape Town: Oxford University Press.

Guba, E.G., \& Lincoln, Y.S. (1994). Competing paradigms in qualitative research. London: Sage.

Hackman, J.R. (2002). Leading teams: Setting the stage for great performances Boston, MA: Harvard Business School Press.

Hein, E. (1980). Communication in nursing practice. Boston, MA: Little Brown.

Herrmann, N., \& Herrmann-Nehdi, A. (2015). The whole brain business book Unlocking the power of whole brain thinking in organisations, teams, and individuals. New York: McGraw-Hill.
Jehn, K.A., \& Mannix, E.A. (2001). The dynamic nature of conflict: A longitudinal study of intragroup conflict and group performance. Academy of Management Journal, 44(2), 238-251. https://doi.org/10.2307/3069453

Johnson, D.W., \& Johnson, F.P. (2006). Joining together: Group theory and group skills (9th edn.). New York: Pearson International.

Joubert, Y.T. (2012). Towards an organisational team sport intervention model for managing a diverse workforce. Unpublished doctoral thesis. Pretoria: University of South Africa.

Jung, D.I. \& Sosik, J.J. (2003). Group potency and collective efficacy: Examining their predictive validity, level of analysis and effects of performance feedback on future group performance. Group and Organisation Management, 28(3), 366-391. https://doi.org/10.1177/1059601102250821

Katzenberg, J.R., \& Smith, D.K. (2015). The wisdom of teams: Creating the high performance organization. Cambridge: Harvard Business School Press.

Kothari, C.R. (2004). Research methodology: Methods and techniques. New Delhi: Washwa Prakashan.

Krefting, I. (1991). Rigor in qualitative research: The assessment of trustworthiness. American Journal of Occupational Therapy, 45(3), 1-15. https://doi.org/10.5014/ ajot.45.3.214

Kvale, S. (1996). Interviews: An introduction to qualitative research interviewing. Thousand Oaks, CA: Sage.

Levi, D. (2014). Group dynamics for teams (4th edn.). Thousand Oaks, CA: Sage.

Lobiondo-Wood, G., \& Haber, J. (2017). Nursing research: Methods and critical appraisal for evidence-based practice (9th edn.). New York: Mosby.

Marks, M.A., Mathieu, J.E., \& Zaccaro, S.J. (2001). A temporally based framework and taxonomy of team processes. Academy of Management Review, 26, 356-376. https://doi.org/10.5465/amr.2001.4845785

Mathieu, J.E., Maynard, M.T., Rapp, T., \& Gilson, L. (2008). Team effectiveness 1997-2007: A review of recent advancements and a glimpse into the future. Journal of Management, 34(3), 410-476. https://doi.org/10.1177/0149206308316061

Maxwell, J.A. (2013). Qualitative research design: An interpretive approach (3rd edn.). Thousand Oaks, CA: Sage.

McGrath, J.E. (1964). Social psychology: A brief introduction. New York: Holt.

Merriam, S.B. (1998). Qualitative research and case study applications in education. Revised and expanded from case study research in education. San Francisco, CA: Jossey-Bass.

Nedelko, Z. (2008). The role and importance of groupware for teamwork. The Business Review, 10(1), 211-217.

Neethling. K. (2005). Creativity uncovered. Wierdapark, Gauteng: Solutionsfinding. Retrieved from http://www.kobusneethling.co.za/.

Patrashkova-Volzdoska, R.R., McComb, S.A., Green, S.G., \& Compton, W.D. (2003) Examining a curvilinear relationship between communication frequency and team performance in cross-functional project teams. IEEE Transactions on Engineering Management, 50(3), 262-269. https://doi.org/10.1109/TEM.2003.817298

Peshkin, A. (1988). In search of subjectivity - One's own. Educational Researcher, 19(7), 17-22. https://doi.org/10.3102/0013189X017007017

Pina, M., Martinez, A., \& Martinez, L. (2008). Teams in organisations: A review on team effectiveness. Team Performance Management, 14(1/2), 7-21. https://doi. org/10.1108/13527590810860177

Pinto, M.B., \& Pinto, J.K. (1991). Determinants of cross-functional cooperation in the project implementation process. Newtown Square, PA: Project Management Institute.

Puth, G. (2008). The communicating leader: The key to strategic alignment. Paarl: Van Schaik.

Ritchie, J., \& Lewis, J. (2003). Qualitative research practice: A guide for social science students and researchers. London: Sage.

Robbins, S.P., \& Judge, T.A. (2009). Organisational behaviour: Global and South African perspectives (2nd edn.). Cape Town: Pearson.

Ross, T.M., Jones, E.C., \& Adams, S.G. (2008). Can team effectiveness be predicted? Team Performance Management, 14(5/6), 248-268. https://doi.org/10.1108/ 13527590810898518

Rudansky-Kloppers, S., \& Strydom, J.J. (2015). Principles of sport management. Cape Town: Oxford University Press.

Schermerhorn, J.R., Osborn, R.N., Uhl-Bien, M., \& Hunt, J.G. (2012). Organisational behaviour (12th edn.). Hoboken, NJ: Wiley.

Sharp, J.M., Hides, M.T., Bamber, C.J., \& Castka, P. (2000). Continuous organisational learning through the development of high-performance teams. ICSTM Electronic Journal of Business Ethics and Organisation Studies, 20(2), (2015).

Shore, L.M., Coyle-Shapiro, J.A., \& Tetrick, L.E. (2012). The employee-organisation relationship: Applications for the 21st century. New York: Routledge.

Stone, A.G., \& Redmer, T.A.O. (2006). The case study approach to scenario planning. Journal of Practical Consulting, 1(1), 7-18.

Swart, C. (2017). Neethling's thinking style preference instrument to enhance team performance in an organisation in South Africa. Unpublished MCom dissertation. performance in an organisation in Sou
Pretoria: University of South Africa.

Tekleab, A.G., Quigley, N.R., \& Tesluk, P.E. (2009). A longitudinal study of team conflict, conflict management, cohesion, and team effectiveness. Group and Organisation Management, 34(2), 170-205. https://doi.org/10.1177/1059601108331218

Tesch, K. (1990). Qualitative research: Analysis, types and software tools. New York: Falmer Press. 
Stickley, T. \& Basset, T. (2008). Learning about mental health practice. John Wiley \& Sons, Ltd, England.

UNISA. (2013). Policy on research ethics. Retrieved from http://www.unisa.ac.za/ research/news/wp-content/uploads/2014/06/Policy-on-Research-Ethics-revappr-Council-20.09.2013.pdf.
Welman, C., Kruger, F., \& Mitchel, B. (2005). Research methodology (3rd edn.). Cape Town: Oxford University Press.

Weiner, I.B. (2012). Handbook of psychology: Industrial and organisational psychology (2nd edn.). Hoboken, NJ: Wiley. 